\title{
Remuneration of Professional Soldiers in the Czech Republic and in the Slovak Republic
}

\section{Odměňování vojenských profesionálů v České republice a Slovenské republice}

\section{Monika Davidová, Vladan Holcner, Miroslav Krč, Alojz Flachbart}

"There is no power without the military, there is no military without money, there are no money without taxes, no taxes without prosperity and no prosperity without laws."

Ancient Sumerian quotation

Abstract: The paper analyses differences in remuneration of professional soldiers in the Czech Republic and the Slovak Republic between 1999 and 2020. This structural analysis focuses on changes in respective remuneration systems and their design. Results of the presented research enable to identify differences in the development of remuneration of professional soldiers after the split of the Czechoslovak Federation in 1993. The paper submits development of the amounts of salary for selected military ranks, their comparison and relation to general trends in domestic labor market and relation to average costs of living in respective countries. Between 2016 and 2019, salaries of professional soldiers grew higher in the Czech Republic than in the Slovak Republic, in 2020 , the pay gap is already narrowing.

Abstrakt: Článek analyzuje odlišnosti v odměňování vojenských profesionálů v České a Slovenské republice v období 1999 - 2020. Strukturální analýzou zkoumá změny systémů odměňování vojenských profesionálů a rozdíly $v$ konstrukci platů. Výsledky a význam publikovaného textu slouží k poznání, do jaké míry se země po rozdělení v roce 1993 posunuly a odlišily v oblasti odměňování vojenských profesionálů. Článek předkládá porovnání úrovně platů vojenských profesionálů ve vybraných vojenských hodnostech a zohledňuje jejich vývoj v relaci k vývoji na trhu práce $v$ daném státě a $v$ relaci $\mathrm{k}$ a výši životních nákladů $v$ daném státě. Růst platů v letech 2016 - 2019 je u vojenských profesionálů ČR vyšší než u vojenských profesionálů SR, v roce 2020 se již rozdíly platů snižují.

Key words: Remuneration of professional soldiers; Salary; Human Resource Management; Military.

Klíčová slova: Odměňování vojáků z povolání; plat; řízení lidských zdrojů; ozbrojené síly. 


\section{INTRODUCTION}

Military expenditures belong to areas of constant and high interest of defense economists. Mainstream of publications dealing with military expenditures are focused on issues connected with allocation scarce national resources to defense. E.g., under conditions of the Czech Republic, rationale and transparent approaches to defense resources allocations are proposed, formulating three courses of action how to deal with deficit in defense resources and instability in Czech military (Mičánek et al., 2014) ${ }^{1}$. Another common approach to military expenditures analyses represents comparisons of trends in selected countries, e.g. assessment of military spending of selected EU nations in 20012008 (Brizgalová, 2012) ${ }^{2}$, covering development of military expenditures in the Czech republic, Austria, Slovakia and Slovenia, or survey of military expenditures of NATO nations (Odehnal, 2015) ${ }^{3}$. Although personnel outlays, incl. compensations of professional military personnel represent a significant and often majority portion of military expenditures, related publications are rather rare, both from international and domestic (Czech) prospective.

Remuneration represents a complex and significant issue for any organization, connected with a number of external as well as internal factors. Reward systems are based on the idea that investments in human capital (which is required to generate adequate return in a form of quantitative of qualitative labor performance) reflects in differentiated compensations of employees according to their merits and contributions to achieving objectives of given organization. Remuneration strategies and processes have to be based on overall strategy of the organization. Kramar et al. $(2012)^{4}$ formulates three components of remuneration systems: financial (incl. basic salary, benefits, performance-related attributes), development (which include career development, abilities, performance, leadership) and social (reflecting organizational climate, balanced working life, wellness programs). Based on Torrington (2014), main components of salary consist of basic rate, premium, overtime, incentive and bonus. ${ }^{\mathbf{5}}$

Remuneration is implemented within compensation policy of given organization, based on its overall strategy and reflecting its position in the market, development intents, economic situation, organizational arrangement, technical parameters, production

1 MIČÁNEK, František. HOLCNER, Vladan. ODEHNAL, Jakub. OLEJNÍČEK, Aleš. ŠULC, František. (2014) Zdrojové zajištění obrany České republiky: Perspektivy a možnosti, Vojenské rozhledy, Vol. 23 (55), No. 3, p. 9-21, ISSN 1210-3292 (tištěná verze), ISSN 2336-2995 (on line), Available at: www.vojenskerozhledy. CZ. DOI 10.3849/1210-3292.23.2014.03.009-021.

2 BRIZGALOVÁLenka.(2012)VojenskévýdajeajejichvyhodnocenívevybranýchzemíchEvropskéunie, Vojenské rozhledy, Vol. 21 (53), No. 4, p. 111-121, ISSN 1210-3292. DOI 10.3849/2336-2995.21.2012.04.111-121.

3 ODEHNAL, Jakub. Military Expenditures and Free-Riding in NATO. Peace Economics, Peace Science and Public Policy, 2015, 21(4), 479-487. ISSN 1079-2457. DOI 10.1515/peps-2015-0015, WOS 000211456100008.

4 KRAMAR, Robin a Jawad SYED. (2012). Human resource management in a global context: a critical approach. New York, NY: Palgrave Macmillan, 2012. p. 246. ISBN 978-0-230-25153-3.

5 TORRINGTON, Derek, Laura HALL a Stephen TAYLOR. (2014). Human resource management. Tenth Edition. New York: Pearson, 2014. p. 415-416. 978-0-273-78663-4. 
activities as well as results of negotiations with social partners. External conditions include primarily legislation and situation in labor market. The aim of the compensation policy/remuneration system is to ensure the needed quality and quantity of personnel, individual will to perform adequately (level of motivation), maintain volumes of salaries at acceptable levels from the point of view of competitiveness in labor market and compensation fairness inside given organizations well as externally in labor market. ${ }^{6}$

Remuneration of professional soldiers is rather specific in individual countries depending on unique mission and objectives of respective national armed forces as well as their organizational arrangement. Since 1993 when the Czechoslovak Federation split into two independent countries, there were subsequent amendments to laws, regulations and decrees, which were reflected in remuneration system of professional soldiers. Let us focus on identification and explanation of potential differences in national remuneration systems of professional soldiers in the Czech Republic and the Slovak Republic.

At the beginning of the 1990s, Act No. 143/1992 Coll., On Salary and Remuneration for On-Call Work in Budgetary and Certain Other Organizations and Bodies, as amended, entered into force and effect. At the same time, it became the starting standard for the Czech Republic and the Slovak Republic. This Act defined the salary and remuneration for on-call time, pay grades and minimum salary tariffs, leadership surcharges, deputizing surcharge, night work, on Saturdays and Sundays, direct pedagogical activities above a specified range, rank surcharge, salary for compensatory leave and overtime work and extra charge. It also defined a bonus for a split shift, a personal bonus, and remuneration, compensatory leave for work on a public holiday and a salary for other work.

\section{METHODS AND DATA}

The paper aims to identify differences in the remuneration of military professionals after the split of the Czech and Slovak Federal Republic in these countries. It also explores what changes emerged within remuneration systems for military professionals in both of the countries, and attempts to quantify the differences in remuneration policies in relation to comparable military personnel categories in the Czech and Slovak Republics.

Methods of studying primary documents, description, analysis and comparison were used throughout the elaboration of this paper. Data used are based on official sources, i.e. legal standards, data from the Czech Statistical Office, the Statistical Office of the Slovak Republic and the Czech National Bank.

The following research questions have been identified in the field of remuneration of military professionals:

6 FLACHBART, Alojz. (2020). Realizace osobních výdajü. Část 1 - Odměňování v resortu obrany. p. 6. ISBN 978-80-7582-371-7. 
- Research question No. 1: What changes have the 1999 - 2020 development of remuneration systems for military professionals in the Czech and Slovak Republics undergone?

- Research question No. 2: What are the current differences in the design of the system of remuneration of professional soldiers of the Czech and Slovak Republics?

- Research question No. 3: What are the differences in the amounts of salary of comparable military personnel in the Czech Republic and the Slovak Republic?

Limitations of the research:

1. The research takes into consideration developments during the period between 1999 and 2020.

2. Comparisons in the systems of remuneration of military professionals are made and differences identified for the 2016 - 2020 period.

3. Comparisons of the amounts of salaries of selected comparable categories of military personnel, incl. their relation to the average salary are made for the 2016 - 2020 period.

4. The article focuses just on the claim components of the salary in given periods; benefits, recruitment contributions, retirement requirements and other non-financial forms of compensation are disregarded within the research.

\section{DEVELOPMENT AND CURRENT STATE OF REMUNERATION OF PROFESSIONAL SOLDIERS IN THE CZECH AND SLOVAK REPUBLIC}

To examine developments and current state in the area remuneration of professional soldiers in the Czech Republic and in the Slovak Republic, it is necessary to perform a description, analysis, modeling and comparison of respective systems in both of the countries.

\subsection{Development and Current State of Remuneration of Professional Soldiers in the Czech Republic}

The area of remuneration of soldiers in the Czech Republic has always been an issue of high interest. The development of remuneration within the Czech defense department in the period from 1999 to 2020 can be divided into three basic periods, namely:

- period from 1999 to 2006,

- period from 2007 to $30^{\text {th }}$ June 2015 ,

- period from $1^{\text {st }}$ July 2015 to 2020.

\section{1. 1 Period of years $1999-2006$}

In the 1990s, remuneration of professional soldiers followed the Act No. 143/1992 Coll. Its implementing regulation were the Government Decrees No. 223/1992 Coll. and No. 79/1994 Coll., on the salaries of employees of the armed forces, security forces and 
services, customs administration bodies, members of the Fire Protection Corps and employees of certain other organizations, as amended. This Government Decree provided salary to civil servants based on determining the pay grade and tariff, surcharges and providing salary in a currency other than Czech. It also included a catalog of jobs and functions, according to which employees were classified into a certain grade according to their job title or function. Furthermore, remuneration of professional soldiers was regulated by the Order of the Minister of Defense No. 33/1994 of the Bulletin, Principles for Remuneration in the Ministry of Defense, which was issued in direct connection with previously issued normative acts and regulated in detail the area of surcharges in the Ministry of Defense. ${ }^{7}$

At the end of the 1990s, Act No. 221/1999 Coll., On Professional Soldiers, as amended, belonged to the basic legal documents defining the remuneration of soldiers in the Ministry of Defense of the Czech Republic. Its fifth part (TITLE I - V) specified salary (basic salary), components of salary (performance surcharge, surcharge for service abroad, special surcharge, surcharge for special responsibility, surcharge for on-call duty, premium), further benefits of soldiers (recruitment, qualification and stabilization contribution, travel and other compensations, food, transport and equipment requisites, health care, medical services, health insurance, sickness insurance, compensation for damage, retirement allowances). In its fourth part, it specified care for soldiers (agreement to increase or expand education, accommodation, service allowance for housing, recreation, one-time financial assistance, retraining, allowance for the funeral of a soldier and a funeral ceremony with military honors). The Act on Professional Soldiers was specified by the Government Decree 330/2003 Coll., On Salary Conditions of Employees in Public Services and Administration, as amended. It defined qualification prerequisites and requirements, classification of an employee into a grade, classification of an employee into a grade, basic salary, special method of determining the salary scale for some employees, personal surcharge, management surcharge, special surcharges and premium.

\section{1. 2 Period from 2007 to $30^{\text {th }}$ June 2015}

The amendment to the Act No. 262/2006 Coll., the Labor Code, was followed by the Government Regulation No. 565/2006 Coll., on the pay of professional soldiers, as amended, effective from $1^{\text {st }}$ January 2007. It was based on the Act No.143/1992 Coll. and copied the structure of the then already expired Government Regulation No. 330/2003 Coll. The Government Regulation No. 565/2006 Coll., was elaborated in detail by the Order of the Minister of Defence No. 44/2006 - internal salary regulation for professional soldiers and by the Order of the Minister of Defence No. 72/2012 - financial management and financial security.

Between 2007 and 2009, several changes took place with regards to the basic salary of professional soldiers. As of 1 January 2007, for the first time in history, basic salary of military professionals was decreased by up to $10 \%$. This was a decision of the Czech Government in response to the economic downturn (in the media and public, this

7 FLACHBART, Alojz. (2020). Realizace osobnich výdajů. Část 1 - Odměňování v resortu obrany. p. 16-17. ISBN 978-80-7582-371-7. 
period is known as the mortgage crisis/banking crisis/banking system crisis, which grew into an economic crisis in the USA and subsequently throughout Europe, incl. the Czech Republic).

At the same time, during the period from 2006 to 2012, demands for changes to the remuneration system for individual groups of employees gradually increased in individual government departments. Every year, there were voices demanding changes in the system of remuneration of employees in various fields (e.g. in the health sector - in state controlled hospitals and other state medical institutions, whose management, together with the unions, responded to demands for changes in the system of remuneration of private doctors so that their salaries would be as equal as possible), demands for changes in the remuneration of teachers, police officers, firefighters and employees of state and local governments, etc. This demands concerned the remuneration of employees of the Ministry of Defence, i.e. professional soldiers as well. The classification of professional soldiers in different appointments (professions) but with the same military ranks into grades has proved to be unsystematic. There were situations where positions with the same military rank but different job descriptions (which determined the appropriate grade) could be classified in a range of up to several (in certain cases up to four or even nine) grades, which meant a very wide range of the amount of actual salary for personnel with the same military rank. ${ }^{8}$

\section{1.3 Period from the $1^{\text {st }}$ July 2015 to 2020}

The basic requirement for the change in the remuneration system was to link the job/ appointment with a military rank and salary (link: position = military rank = salary). On this basis, adjustments of the rank structure were made across the entire organizational structure of the Czech Armed Forces in order to comply with the requirement to link the rank to a given systematized position in the context of the interdependence of the entire rank structure from the bottom to the top or vice versa.

Based on the amendment to the Act No. 221/1999 Coll., on professional soldiers, as amended by the Act No. 332/2014 Coll., a completely new system of remuneration for military professionals has been introduced on $1^{\text {st }}$ July 2015 . It has abandoned the system of assigning a systematized position to the appropriate grade according to the set of the most extensive and complex activities carried out in that position/appointment. "A soldier shall be entitled to a salary for the performance of his/her service in an amount appropriate to his/her appointment, conditions of service and service performance." ${ }^{\text {"9 }}$ The salary was a remuneration for the service (work) performed, similarly to the remuneration for employees in an employment relationship. The particular amount of the salary of each soldier was decided by his/her service authority by means of a personnel order under the service procedure. The service authorities had to comply with this special remuneration arrangement, where the principle that "what is not prohibited is permitted" does not apply, as in the case of a business sphere. Accordingly, it was not possible to determine the salary in a different way, in a different composition and in

8 Ministry of Defence of the Czech Republic ČR, A report No. 2/2015, MoD Prague, ISSN 1211-801X, p. 6.

$9 \S 66$, art. 1 of the Act No. 221/1999 Coll., on professional soldiers, as amended. 
a different amount from that provided for by the Act and the regulations made for its implementation. The new legislation on remuneration, effective from $1^{\text {st }}$ July 2015 , was completely different from the previous legislation set out in the Act No. 143/1992 Coll., on salary and remuneration for on-call time in budgetary and certain other organizations and bodies.

The essence of this change was the intrinsic nature of a soldier's service, where the basic task of the armed forces (and therefore also of a military professionals) is to prepare for the defense of the Czech Republic and to defend it against external attack. From this task arose the requirement for the actual performance of the military service and related duties, regardless of the time of night or day, individual days of the week, public holidays, etc. Therefore, night, weekends and some other allowances (such as leadership allowance, hardship allowance and rank surcharge) have been abolished. The salary has now taken a different form.

According to the new salary regulations, fixed service tariffs have been assigned to individual ranks for specific positions. An Annex to the Government Regulation No $60 / 2015$ Coll., on the determination of the list of activities for individual military ranks, as amended, includes a list of soldiers' activities specified for individual military ranks depending on their complexity, responsibility and exertion. The basic component of the salary was determined taking into account not only the most demanding types of service required, but also the requirements for leadership skills, the general risk of the military profession and the length of service already rendered. The service tariffs have effectively included the pay scale, leadership allowance, rank allowance, special allowance for work connected with the preparation to and assurance of national defense and personal allowance from the old system. In addition, it has included a lump-sum allowance for service at night, on days of continuous weekly rest, on public holidays and overtime. The minimum amounts of the service tariffs have been established by law, while the currently applicable entitlement amounts have been set out in the Government Regulation No. 59/2015 Coll., on service tariffs and special allowance for professional soldiers, as amended. Between 2015 and 2020, service tariffs have been repeatedly valorized. Table 1 shows an overview of the entitlement components of the salary of professional soldiers in the Czech Republic. 
Table 1: Overview of the entitlement components of the salary of military professionals of the Czech Republic based on the salary scale/personnel order (1999-2020)

\begin{tabular}{|c|c|c|c|}
\hline & $1999-2006$ & $2007-30^{\text {th }}$ June 2015 & 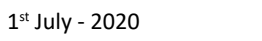 \\
\hline Enacted & Salary scale & Salary scale & Personnel order \\
\hline $\begin{array}{l}\text { Salary } \\
\text { components }\end{array}$ & $\begin{array}{l}\text { - salary category + sala- } \\
\text { ry grade = basic salary } \\
\text { - personal surcharge } \\
\text { - leadership surcharge } \\
\text { - special surcharge } \\
\text { - rank surcharge } \\
\text { - night work surcharge } \\
\text { - Saturdays and Sunda- } \\
\text { ys work surcharge } \\
\text { - pay for compensatory } \\
\text { time off and overtime } \\
\text { - pay for compensatory time off } \\
\text { for working on public holidays } \\
\text { - bonus } \\
\text { - deputizing surcharge } \\
\text { - surcharge for direct tea- } \\
\text { ching activities beyond } \\
\text { the specified scope } \\
\text { - split shift surcharge } \\
\text { - salary for other work }\end{array}$ & $\begin{array}{l}\text { - salary category + sal- } \\
\text { ary grade = basic salary, } \\
\text { - personal surcharge } \\
\text { - leadership surcharge } \\
\text { - special surcharge } \\
\text { - rank surcharge } \\
\text { - night work surcharge } \\
\text { - Saturdays and Sun- } \\
\text { days work surcharge } \\
\text { - pay for compensatory } \\
\text { time off and overtime } \\
\text { - pay for compensatory } \\
\text { time off for working } \\
\text { on public holidays } \\
\text { - bonus } \\
\text { - extra pay for working } \\
\text { in deteriorated work- } \\
\text { ing environments }\end{array}$ & $\begin{array}{l}\text { - service tariff, } \\
\text { - performance } \\
\text { surcharge } \\
\text { - surcharge for } \\
\text { service abroad } \\
\text { - special surcharge } \\
\text { - increased respon- } \\
\text { sibility surcharge } \\
\text { - on-call allowance } \\
\text { - bonus }\end{array}$ \\
\hline $\begin{array}{l}\text { Further } \\
\text { benefits }\end{array}$ & - housing benefit & - housing benefit & $\begin{array}{l}\text { - stabilization } \\
\text { benefit (taxed) } \\
\text { • service housing } \\
\text { benefit (tax exempt) }\end{array}$ \\
\hline
\end{tabular}

\subsection{Development and Current State of Remuneration of Professional Soldiers in the Slovak Republic}

Between the years 1999 and 2020, remuneration of professional soldiers of the Armed Forces of the Slovak Republic has undergone a development similar to the development in the Czech Republic. We can distinguish three basic stages, each of them related to certain set of measures aimed and enhancing attractiveness of military service:

- period from 1999 to 2004 ,

- period from 2005 to 2015 ,

- period from 2016 to 2020 .

\section{2. 1 Period from 1999 to 2004}

In 1997, a new Act No. 370/1997 Coll. on military service was issued, which defined and regulated the legal relations between soldiers in the so-called compulsory military service and the state, connected with the establishment, changes and termination of compulsory military service. It also defined some basic concepts such as soldier, service body, its rights and duties as well as limitations of some constitutional rights of soldiers. This Act was followed by the Act No 380/1997 Coll. on remuneration of soldiers, dated $11^{\text {th }}$ December 1997, effective as of $1^{\text {st }}$ January 1998 , which set out the individual components of the salary of professional soldiers, conscripts and reserve soldiers called up for military training. This legal regulation was in force until 2002. 
At that time, salary of professional soldiers consisted of the following components: functional salary, surcharge for years in service, supplement for not carrying out business and other profit making activity, rank surcharge, leadership surcharge, substitution surcharge, personal surcharge, night duty surcharge, Saturday and Sunday duty surcharge and holiday duty surcharge. These salary components were subject to taxation according to the standards in force at the time.

In 2002, the Act No 328/2002 Coll. of 29 May 2002 on the social security of police officers and soldiers and on amending and supplementing certain acts was issued. This law did not regulate the amount of salaries or their components, but only the area of social security services, accident insurance, sickness insurance and the calculation of average earnings for the application of individual compensations.

\section{2. 2. Period from 2005 to 2015}

A real changeover in the armed forces of the Slovak Republic meant the year 2005 and approval of the Act No. 346/2005 Coll. of $23^{\text {rd }}$ June 2005 on the State Service of Professional Soldiers of the Armed Forces of the Slovak Republic and on Amendments and Additions to Certain Acts, effective as of 1st July 2005. It is similar to the Act No. 221/1999 Coll. on professional soldiers in the Czech Republic. It addresses the whole area of the professional military service, including remuneration, social security and administrative procedures. Its title $8, \S 138$ et seq. set out a new salary structure for professional soldiers. Salaries of professional soldiers included: rank salary, salary compensation for national service, surcharge for active airmen and paratroopers, surcharge for members of military intelligence, military police and medical personnel, surcharge for leading troops to the training area, surcharge for military top athletes, deputizing surcharge and allowance for service abroad.

\section{2. 3. Period from 2016 to 2020}

During the ten years of the validity of Act No 346/2005 Coll., there have been certain social and political tendencies in Slovakia, which have led to the fact that the development of modern, relatively small, but well-trained armed forces of the Slovak Republic started to have problems with human resources. Reaction to this was an effort to eliminate the growing migration of young, educated and capable potential and current professional soldiers not only from the Armed Forces of the Slovak Republic, but also from outside the territory of the country, (mainly due to higher salaries). Therefore, the Ministry of Defence of the Slovak Republic had to come up with a new legislative regulation of the civil service so that the military profession would become competitive on the labor market.

The new Act No. 281/2015 Coll., on the State Service of Professional Soldiers and on Amendments and Additions to Certain Acts, as amended, has changed the philosophy of the state service of professional soldiers. As for the best soldiers, service can become almost or completely a lifelong profession. For this reason, the scale of rank salaries has also been adjusted. Such a decision obviously had an impact on the budget of the Ministry of Defence of the Slovak Republic, which, however, was neutralized by savings in other components of the salary and other benefits in order not to increase the overall spending of the Ministry of Defence. The $\S 156$ et seq. of the above-mentioned Act has defined components of the salary of professional soldiers of the Armed 
Forces of the Slovak Republic since $1^{\text {st }}$ January 2016. The remuneration of professional soldiers has been completely based on the previous system, where the basis of remuneration according to military ranks and the provision of supplements to the rank salary have been maintained, but due to the new career system it has been necessary to make some changes. The basic characteristics of the allowances have been taken over from the previous legislation, but the allowance for taking troops to the training area has been abandoned. In connection with this, the number of salary components, which are no longer used for calculating, for example, pro rata parts of the salary, has been reduced by one third. The salary of a professional soldier has now consisted of the sum of six basic components, namely: rank salary, salary compensation for hardship in the performance of state service, surcharge for selected specialized functions (military police, medical personnel, military intelligence, airmen, sportsmen); deputizing surcharge/surcharge for the performance of a vacant command function, foreign allowance and bonus. The housing allowance has been transformed into a stabilization allowance, which has been paid monthly to professional soldiers in temporary and permanent state service.

In October 2019, a new Act No. 377/2019 Coll. has been issued, supplementing the Act No. 281/2015 Coll. on the Civil Service of Professional Soldiers and on Amendments and Additions to Certain Acts, as amended. This law was set to take effect on $1^{\text {st }}$ February 2020. In addition to personnel issues such as promotion time to higher rank, medical fitness assessment, studies of professional soldiers and others, its Annex 3 has set out new rank salaries and service tariffs applicable from $1^{\text {st }}$ February 2020. Table 2 submits an overview of the entitlement components of salaries of military professionals of the Slovak Republic based on the salary assessment/personnel order (1999 - 2020).

Table 2: Overview of the entitlement components of the salary of military professionals of the Slovak Republic based on the salary scale/personnel order (1999-2020)

\begin{tabular}{|c|c|c|c|}
\hline & 1999 - 2004 & $2005-2015$ & 1. $1.2016-2020$ \\
\hline Enacted & Salary scale & Personnel order & Salary scale \\
\hline $\begin{array}{l}\text { Salary } \\
\text { components }\end{array}$ & $\begin{array}{l}\text { - functional salary, } \\
\text { - surcharge for } \\
\text { years in service, } \\
\text { - supplement } \\
\text { for not carry- } \\
\text { ing out business } \\
\text { and other profit } \\
\text { making activity, } \\
\text { - rank surcharge, } \\
\text { - leadership } \\
\text { surcharge, } \\
\text { - deputizing } \\
\text { surcharge, } \\
\text { - personal surcharge, } \\
\text { - night service } \\
\text { surcharge, } \\
\text { - surcharge for } \\
\text { service on Satur- } \\
\text { days and Sundays, } \\
\text { - surcharge for } \\
\text { service on holidays. }\end{array}$ & $\begin{array}{l}\text { - rank salary, } \\
\text { - compensation for } \\
\text { state service, } \\
\text { - surcharge for active } \\
\text { airmen and paratroopers, } \\
\text { - surcharge for mil- } \\
\text { itary intelligence, } \\
\text { military police and } \\
\text { medical personnel, } \\
\text { - surcharge for mili- } \\
\text { tary top athletes, } \\
\text { - deputizing surcharge, } \\
\text { - allowance for } \\
\text { service abroad, } \\
\text { - surcharge for lead- } \\
\text { ing troops to the } \\
\text { training area. }\end{array}$ & $\begin{array}{l}\text { - rank salary, } \\
\text { compensation for } \\
\text { hardship in the perfor- } \\
\text { mance of state service, } \\
\text { - surcharge for } \\
\text { selected appoint- } \\
\text { ments (military police, } \\
\text { military intelligence, } \\
\text { airmen, athletes), } \\
\text { - deputizing surcharge/ } \\
\text { surcharge for the per- } \\
\text { formance of a vacant } \\
\text { command function, } \\
\text { - allowance for } \\
\text { service abroad, } \\
\text { - bonus. }\end{array}$ \\
\hline $\begin{array}{l}\text { Further } \\
\text { benefits }\end{array}$ & zation benefit & zation benefit & $\begin{array}{l}\text { zation benefil } \\
\text { zati- }\end{array}$ \\
\hline
\end{tabular}




\section{PRESENTATION OF FINDINGS}

In the Czech Republic as well as in the Slovak Republic, the remuneration of military professionals has changed between the 1990s and 2020, in both the compensation system and its design.

\subsection{Comparison: Similarities and differences}

In the Czech Republic, from 1999 to 30 June 2015, civil servants were paid based on grades and tariffs and other allowances. It also included a catalogue of jobs and functions, according to which employees were classified in a certain grade according to given position or function and nature of related workload. However, this classification of jobs with the same military rank into grades has proven to be unsystematic. There were cases where a position with the same military rank but different job descriptions could be classified in a range of up to four grades, which meant a very wide range for the pay rate.

Between 2007 and the $30^{\text {th }}$ June 2015, the range of salary components were reduced and some allowances were abolished (deputizing allowances, allowances for direct teaching activities beyond the defined scope, salary for other work etc.).

On the $1^{\text {st }}$ July 2015 , a completely new system of remuneration for military professionals has been introduced. It eliminated the mechanism of assigning individual positions to the appropriate grades according to the set of the most extensive and complex activities carried out and introduced the so-called service tariffs. The new salary regulations assigned a fixed service tariff to the individual ranks established for specific positions (for individual military ranks depending on their complexity, responsibility and workload). The service tariff effectively included the pay scale, leadership surcharge, rank surcharge, special surcharge for work connected with the preparation and provision of national defense and personal surcharge from the old system, and also included a lump-sum allowance for service at night, on weekends on public holidays and overtime. Minimum rates of service tariffs were set by law. During this period, the salary was anchored in the personnel order. Between the $1^{\text {st }}$ July 2015 and 2020, the components of the salary have been changed, with the following new provisions: performance surcharge, foreign service surcharge, special surcharge, extra responsibility surcharge, standby duty surcharge and bonus. Housing benefit has been abolished and replaced by the stabilization and housing allowances.

In the Slovak Republic, new legislation in 1997 defined and regulated the legal relations between soldiers in so-called compulsory military service and the state, related to the establishment, changes and termination of compulsory military service. Subsequently, in 1998, it established individual components of the pay of professional soldiers, conscripts and soldiers called up for training. In 2002, another statutory change defined only the issues of social security services, accident insurance, sickness insurance and retirement security for soldiers and the calculation of average earnings for the application of individual compensation. In 2005, a law was issued that addressed the entire issue of 
professional soldiers' service, including remuneration, social security and administrative procedures.

A significant change in the area of remuneration took place in 2016, when the philosophy of the civil service of professional soldiers was changed and the scale of rank salaries was adjusted. The basic characteristics of the allowances are taken over from the previous legislation, the salary components have been reduced. The salary of a professional soldier considered again national service performed at night, on rest days, overtime not exceeding five hours per week and on call. The surcharge for taking troops to the training area has been waived. The salary of a professional soldier consisted of the sum of six basic components, namely: rank salary, salary compensation for hardship in the performance of state service, surcharges for selected specialized functions (military police, medical personnel, military intelligence, airmen, sportsmen); deputizing surcharge/ surcharge for the performance of a vacant command function, foreign service allowance and bonus. In 2020, new rank salaries have been set.

Table 3 submits an overview of the entitlement components of the salary of military professionals in the Czech Republic and the Slovak Republic.

Table 3: Overview of the entitlement components of the salary of military professionals in the Czech Republic and the Slovak Republic based on the salary scale/personnel order (2015 - 2020)

\begin{tabular}{|c|c|c|}
\hline & Czechia 1. 7. 2015 - 2020 & Slovakia 1. 1. 2016 - 2020 \\
\hline Enacted & personnel order & salary scale \\
\hline $\begin{array}{l}\text { Salary } \\
\text { components }\end{array}$ & $\begin{array}{l}\text { - service tariff } \\
\text { - performance surcharge } \\
\text { - surcharge for service abroad } \\
\text { - special surcharge } \\
\text { - increased responsi- } \\
\text { bility surcharge } \\
\text { - on-call allowance } \\
\text { - bonus }\end{array}$ & $\begin{array}{l}\text { - } \quad \text { rank salary } \\
\text { compensation } \\
\text { for hardship in the perfor- } \\
\text { mance of state service } \\
\text { - } \quad \text { surcharge for selected } \\
\text { appointments (military police, mili- } \\
\text { tary intelligence, airmen, athletes) } \\
\text { - deputizing surcharge/ } \\
\text { surcharge for the performance } \\
\text { of a vacant command function } \\
\text { - allowance for } \\
\text { service abroad } \\
\text { - bonus }\end{array}$ \\
\hline Further benefits & $\begin{array}{l}\text { - stabilization benefit } \\
\text { - service housing allowance }\end{array}$ & - stabilization benefit \\
\hline
\end{tabular}

\subsection{Salaries of military professionals and selected economic indicators in the Czech Republic and the Slovak Republic}

The amount salary of military professionals in itself is not a relevant variable unless related to selected economic indicators (e.g. ratio to average wage). As a model, this paper will further use three selected military ranks (sergeant, lieutenant and colonel) and their marital status and appointment (sergeant - single - driver; lieutenant - married with 1 child - platoon leader; colonel - married - no children - brigade commander). 
Between 2016 and 2020, average salary in the Czech Republic exceeds the average salary in Slovakia. In 2016, the average salary gap was $€ 173$ and the gap increased in subsequent years, reaching €324 in 2020.

Table 4: Amounts of salary of selected categories of professional soldiers and selected economic indicators in the Czech Republic and the Slovak Republic

\begin{tabular}{|l|l|l|l|l|l|}
\hline & 2016 & 2017 & 2018 & 2019 & 2020 \\
\hline Average wage CZ (€) & 1085 & 1202 & 1320 & 1407 & 1457 \\
\hline Average wage SVK $(€)$ & 912 & 954 & 1013 & 1092 & 1133 \\
\hline Difference $(€)$ & 173 & 248 & 307 & 315 & 324 \\
\hline Sergeant CZ (€) & 957 & 1126 & 1155 & 1178 & 1219 \\
\hline Sergeant SVK (€) & 762 & 820 & 820 & 820 & 1244 \\
\hline Difference $(€)$ & 195 & 306 & 335 & 358 & -25 \\
\hline Lieutenant CZ (€) & 1197 & 1425 & 1463 & 1490 & 1495 \\
\hline Lieutenant SVK $(€)$ & 879 & 936 & 936 & 936 & 1406 \\
\hline Difference $(€)$ & 318 & 489 & 527 & 554 & 89 \\
\hline Colonel CZ $(€)$ & 1962 & 2438 & 2503 & 2686 & 2854 \\
\hline Colonel SVK (€) & 1180 & 1247 & 1247 & 1247 & 2006 \\
\hline Difference $(€)$ & 782 & 1191 & 1256 & 1439 & 848 \\
\hline
\end{tabular}

Source: Own based on official data of the Czech and Slovak national statistical authorities.

In 2016-2020, military professionals in the Czech Republic earned higher salary than military professionals in Slovakia. In 2016, for the military rank of sergeant the difference represented $€ 195$, for the rank of lieutenant $€ 318$ nevertheless, a rather significant difference can be seen for the rank of colonel, where the salary difference was up to $€$ 782. In 2017, the difference in the military rank of sergeant was $€ 306$, in the rank of lieutenant $€ 489$, but we can see even higher difference in the rank of colonel, where the difference in salaries represented $€ 1,191$. In 2018, the difference for the military rank of sergeant was $€ 335$, for the rank of lieutenant $€ 527$ and $€ 1,256$ for colonels. In 2019 , the difference for the military rank of sergeant was $€ 358$, for the rank of lieutenant $€ 574$ and even $€ 1,439$ for the rank of colonel. A turnaround occurred in 2020, when a military professional in the Czech Republic earned a salary higher than a military professional in Slovakia only for the ranks of lieutenant (difference of $€$ 89) and colonel (difference of $€$ 88). A sergeant in Slovakia earned a salary of $€ 25$ higher than in Czechia then. 
Charts 1 and 2 show the amounts of salaries of given categories of military professional as well as selected economic indicators in both of the countries. The Chart 3 presents the amounts of salary of selected categories of professional soldiers, amounts of salary of selected professions and costs of living without housing in both of the countries.

\section{Economic Indicators CZ}

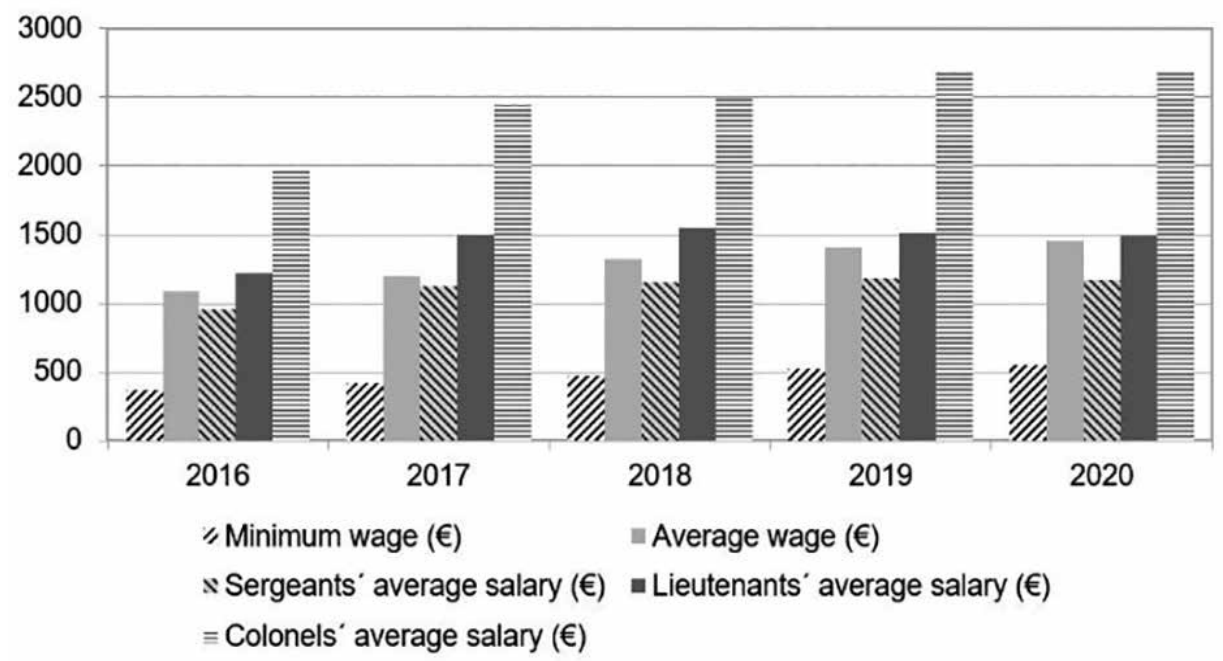

\section{Economic Indicators SVK}

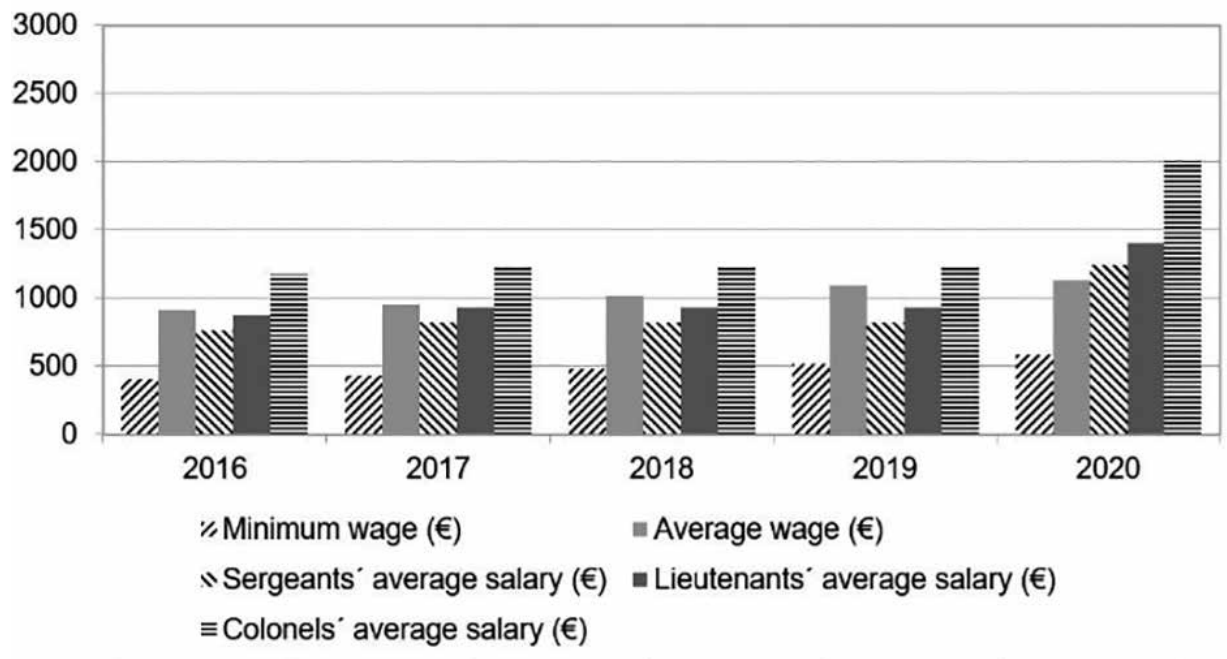

Chart 1: Economic indicators in Czechia

Chart 2: Economic indicators in Slovakia 


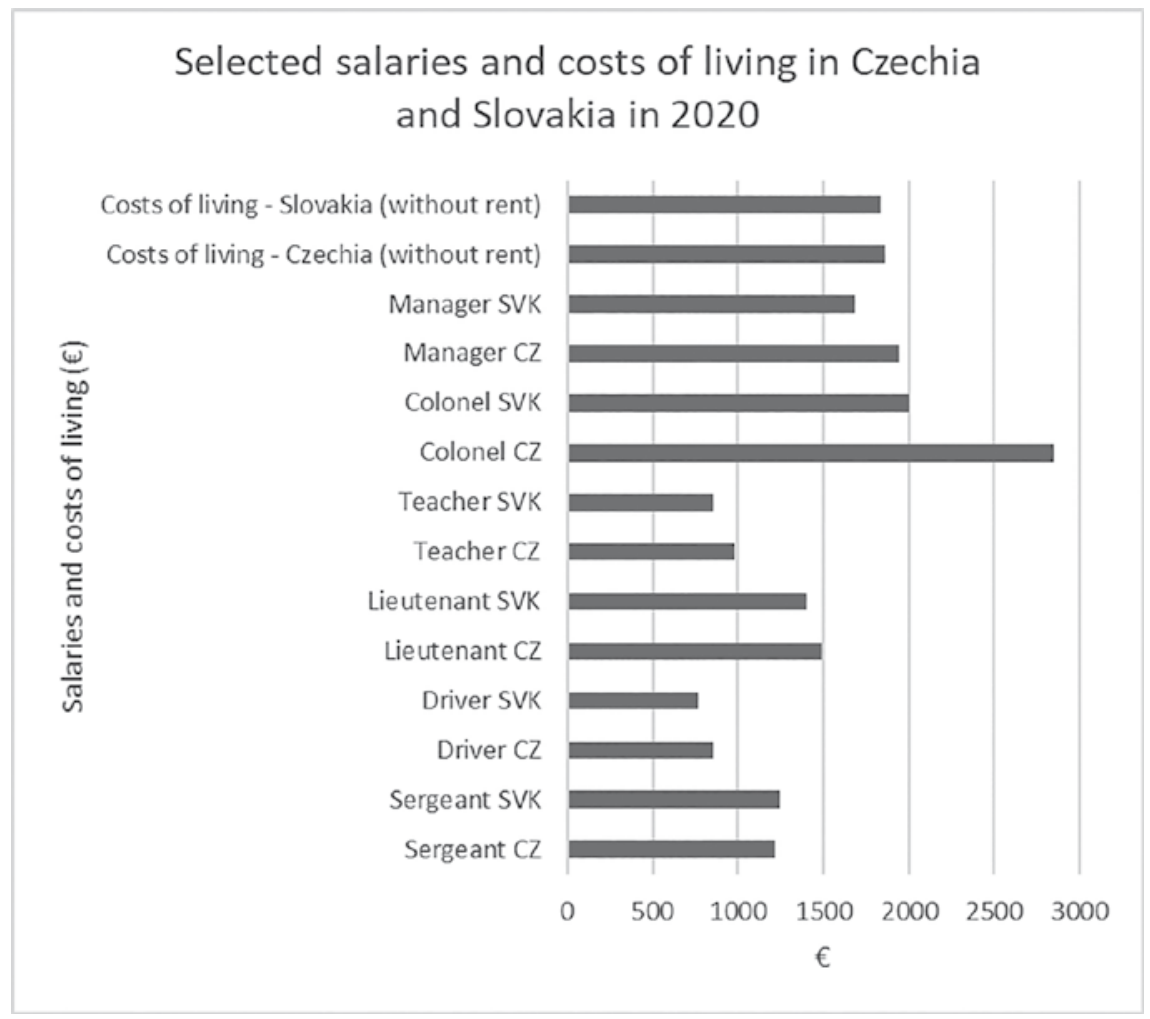

Chart 3: Economic indicators in Czechia

Source: Own, based on Numbeo and PlatoMetr. ${ }^{10}$

\section{DISCUSSION}

Question 1: What changes have occurred in the development of remuneration systems for military professionals in the Czech and Slovak Republics 1999 - 2020?

Since the dissolution of the federation, the development of remuneration systems for military professionals in both countries has undergone significant changes. Changes to statutory norms and related internal regulations have gradually regulated not only the issue of remuneration, i.e. salary, its anchorage, salary components, other financial allowances, but also the issue of social, accident, sickness, retirement security, administrative proceedings,

10 NUMBEO. Cost of Living. Available at: <https://www.numbeo.com/cost-of-living/>. [Cit. 2021-10-08].; PlatoMetr. Available at: < https://mujplat.cz/platy-v-cr/platometr\#//> [Cit. 2021-10-06] 
calculation of average earnings for the application of compensation and personnel issues such as the time of promotion to a higher rank, assessment of medical fitness, studies etc.

Question 2: What are the differences in the design of the remuneration system for professional soldiers of the Czech and Slovak Republics 1999 - 2020?

In the Czech Republic, the design of the remuneration system for military professionals has changed in all parts of the salary components. Until 2015, the salary was dealt with by the basic salary, anchored in the salary scale. The spectrum of individual salary components was reduced until 2015. From 2015 to 2020, the salary have consisted of service tariffs and up to six further salary components, anchored by a personnel order. Housing allowance has been transformed to the stabilization benefit and the service housing allowance.

In Slovakia, the design of the remuneration system for military professionals has also changed in all parts of salary components. During the period 1999-2015, changes were made to different salary components, with functional salary replacing rank salary, abolishment of selected allowances and their replacement by new salary components. Salary has been anchored by the salary assessment, with continuously provided housing allowance - see Tables 2 and 3.

Question 3: What is the difference of the amount of salary of comparable categories of military professionals in the Czech and Slovak Republics?

Generally, between 2016 and 2019, professional soldiers in Czechia earned higher salary compared to professional soldiers in Slovakia. For the rank of sergeant the difference is on average $261 €$, for the rank of lieutenant $472 €$ and for the rank of colonel $1167 €$. However, in 2020, the situation changed, for the rank of sergeant the salary in the Czech Republic was 25 $€$ lower than for a sergeant in the Slovak Republic for other monitored ranks the difference is lower than in previous years.

The average salary of a military professional in Czechia at the rank of sergeant represented $180 \%$ of the average salary in the Czech economy, at the rank of lieutenant $210 \%$ and colonel $290 \%$. The average salary of a military professional in Slovakia at the rank of sergeant represented $180 \%$ of the average salary in the Slovak economy, at the rank of lieutenant $190 \%$ and colonel $230 \%$. When comparing the salaries of selected military ranks in the Czech Republic and Slovakia with the salaries of selected civilian professions, it is evident that in 2020 there were analogous differences, hence analogous positions of military professionals among employees in domestic society. An exception is the comparison of the salaries of military professionals in the rank of sergeant and the salaries of drivers in both countries, which indicates relatively lower level of remuneration of Czech military personnel in this category. A look at the almost equal cost of living (excluding rent) in both countries indicates a stronger economic position of Czech military professionals in relation to the situation in Slovakia. There is one exception again - the rank of colonel in the Czech Republic, which is connected with significantly higher salary in re. An overview of the cost of living and salaries of selected professions in the Czech Republic and Slovakia submits Table 5.

\section{CONCLUSION}

This paper submits an analysis of trends and differences in remuneration of professional soldiers in the Czech and Slovak Republics in the period of 1999 - 2020. A structural 
analysis focuses on changes in respective national remuneration systems for professional soldiers, examines changes in the design of both systems in time, differences in structure of the systems and analyses relative position of professional soldiers in society through comparison with average wage in both economies, salaries of comparable civilian professions and the costs of living in respective countries.

Data show that between 2016 and 2019 the salary growth of professional soldiers in Czechia was higher than that of military professionals in Slovakia. On average, the difference was $€ 261$ ( 0.8 times the average salary) for the rank of sergeant, €472 (1.1 times the average salary) for the rank of lieutenant and €1,073 (1.9 times the average salary) for the rank of colonel. In Slovakia, the average salary of a professional soldiers exceeded average wage in Slovak economy - for sergeants 0.8 times the average salary, for lieutenants 0.9 times the average salary and for colonel 1.3 times the average salary. In 2020, the differences between the ranks of lieutenant and colonel decreased and the salary of a sergeant in Slovakia even exceeded that of a sergeant in Czechia by 25 Eur. The costs of living (excluding rent) in $\mathbf{2 0 2 0}$ were approximately the same in Czechia and Slovakia; salaries of professional soldiers exceeded the amounts of salaries of selected comparable civilian professions.

Results of this research contribute to understanding of trends and differences in remuneration of professional soldiers in both successor states after the split of the Czechoslovakia in 1993.

This paper as well as the research presented has been supported by specific university research project at the Faculty of Military Leadership Financováni a ekonomické rízení prí zajišt'ování bezpečnosti a obrany (Funding and economic management in national dense and security), SV18-FVL-K102-MUS, and applied research within the research project of institutional research support Aplikovaná ekonomie v rezortu obrany (Applied economics in defense department), AERO K-102, University of Defence, Faculty of Military Leadership, Resource Management Department.

Authors: $\quad$ Monika Davidová, PhD., born 1975, is a graduate of the Military College of the Ground Forces in Vyškov (Ing., 2003), University of Defence (Ph.D., 2008). Her academic career includes positions of lecturer at the Department of Social Sciences and Law of the Faculty of Economics and Logistics of the Military College of the Ground Forces in Vyškov, senior lecturer at the Department of Human Resources Management of the Faculty of Economics and Management of the University of Defence in Brno. At present, she works as a senior lecturer of the Department of Resources Management of the Faculty of Military Leadership, University of Defence. Her pedagogical and research activities focus on the area of human resources management and labor market.

Col. Assoc. Prof. Vladan Holcner, PhD., born 1975, is a graduate of the Military College of the Ground Forces in Vyškov (Ing., 1998), University of Defence (Ph.D., 2005), Marshall Centre for Security Studies in Garmisch-Partenkirchen 
(2002) a Naval Postgraduate School in Monterey, CA, USA (2006). He has served at various appointments within the Department of Economics of the University of Defense in Brno, between 2010 and 2019 acted as the Dean of the Faculty of Military Leadership. Since, 2019, he has been appointed the Director of the Language Centre of the University of Defence. His pedagogical and research activities focus on the area of military expenditures, their effectiveness and efficiency, international armaments cooperation and human resources in military. Recently, he has been involved in issues of language training effectiveness as well. He has published numerous articles in domestic as well as international scientific journals.

Libor Jilek, born 1967, is a graduate of the Human Resources Management master degree program at the Military College of the Ground Forces in Vyškov (2001). Between 1987 and 2001, he served as a human resources officer of the independent airfield battalion and the 33rd helicopter air base in Prerov-Bochor. Between 2001 - 2004 he served as a lecturer at the Department of Social Sciences and Law at the Military College of the Ground Forces in Vyškov. Since 2004, he has worked at the University of Defence, at present as a lecturer of the human resources section of the Department of Resources Management of the Faculty of Military Leadership, University of Defence. He deals with issues of demographic developments in the Czech Republic and their implications for recruitment in the Czech Armed Forces.

Alojz Flachbart, PhD., born 1953, is a graduate of the Military College of Logistics and Maintenance in v Žilina, Slovakia (1979), Military Academy in Brno (postgraduate program, 1987) Between 1979 and 1992, he served as financial service officer at the levels of battalion and brigade. Between 1993 and 2002 he served as a director of the military financial office in Hodonín. Since 2005, he has worked at the Department of Resources Management of the Faculty of Military Leadership, University of Defence in Brno. He deals with issues connected with renumeration, social security and taxation in public sector, defense department in particular. He has published several articled and study texts focused on the above-mentioned areas, both in the Czech Republic and abroad.

How to cite: DAVIDOVÁ, Monika, Vladan HOLCNER, Miroslav KRČ and Alojz FLACHBART. Remuneration of Professional Soldiers in the Czech Republic and in the Slovak. Vojenské rozhledy. 2021, 30 (4), 123-140. ISSN 1210-3292 (print), 23362995 (on-line). Available at: www.vojenskerozhledy.cz. 